Open Access

\title{
Comparative analysis of therapeutic efficiency and costs (experience in Bulgaria) of oral antidiabetic therapies based on glitazones and gliptins
}

\author{
Elena Pavlova Filipova ${ }^{1 *}$, Katya Hristova Uzunova ${ }^{1}$ and Toni Yonkov Vekov ${ }^{2}$
}

\begin{abstract}
Type 2 diabetes mellitus is a serious, chronic, progressive and widespread disease. Metformin is the most commonly prescribed initial therapy, but combination with other antidiabetic agents usually becomes necessary due to the progression of the disease. Pioglitazone is recommended as a second-line therapy because of its strong antihyperglycemic effect and its ability to reduce insulin resistance. Treatment with pioglitazone is associated with a significantly lower risk of cardiovascular complications and hypoglycemia, while simultaneously improving the lipid profile and the symptomatic and histological changes in the liver. Gliptins (sitagliptin and vildagliptin) are a new class of oral antidiabetic drugs which reduce glycated hemoglobin by a different mechanism. Although the efficacy of sitagliptin and vildagliptin is close to that of pioglitazone, the lack of long-term safety data and the higher price question their predominant use. The objective of this review is to highlight the advantages of mono- and combination therapy with pioglitazone in comparison with gliptins and to underline the inconsistencies in the medicinal and reimbursement policy in Bulgaria.
\end{abstract}

Keywords: Type 2 diabetes, Pioglitazone, Gliptins, Efficiency, Safety

\section{Introduction}

Type 2 diabetes mellitus (T2DM) is a global epidemic with an estimated worldwide prevalence of 246 million people (6\%) in 2007 and the number is expected to reach 380 million (7.3\%) by 2025 [1]. As a chronic disease with serious consequences, T2DM requires costly therapy and care. Metformin is the most commonly prescribed first-line therapy in the world, but due to progressive deterioration of blood glucose control during the natural progression of the disease, combination therapy usually becomes a necessity.

Thiazolidinediones (TZDs), such as pioglitazone, are a class of antidiabetic drugs that exert their action by binding to peroxisome proliferator-activated receptor gamma (PPAR- $\gamma$ ) [2]. Peroxisome proliferator-activated receptors (PPARs) are expressed in various tissues: kidney, heart, muscle, adipose tissue (PPAR- $\alpha$ ); heart, muscle, colon,

\footnotetext{
* Correspondence: e.filipova.hq@tchaikapharma.com

${ }^{1}$ Science Department, Tchaikapharma High Quality Medicines, Inc, 1 G.M.

Dimitrov Blvd, 1172 Sofia, Bulgaria

Full list of author information is available at the end of the article
}

kidney, pancreas, spleen, macrophages, white adipose tissue (PPAR- $\gamma)$; brain, adipose tissue and skin (PPAR- $\delta$ ) [3]. The primary role of PPAR- $\gamma$ appears to be in regulating glucose and lipid metabolism along with adipogenesis. PPAR- $\gamma$ is thought to enhance the actions of insulin [4]. TZDs bind specifically with PPAR- $\gamma$ and by activating these receptors they perform a variety of biological functions such as the reduction of insulin resistance, which is responsible for their application as anti-hyperglycaemic agents. Gliptins are a new oral drug class for the treatment of T2DM which reduce blood sugar (glucose) levels by a different mechanism. They inhibit the enzyme dipeptidyl peptidase-4 (DPP-4), thereby increasing the circulating levels of incretins (gut hormones that enhance insulin secretion). Sitagliptin and vildagliptin belong to this drug class.

According to the therapeutic guidelines of the National Institute for Health and Care Excellence (NICE) glitazones are recommended as second-line therapy in patients who fail to achieve adequate glycemic control (glycated hemoglobin $\left.\left(\mathrm{HbA}_{1 \mathrm{c}}\right) \geq 6.5 \%\right)$ after administration of 
metformin and/or sulphonylureas, especially if the person has marked insulin sensitivity [5]. Gliptins are also recommended as a second line of therapy, and may be preferable to TZDs in case of problems with weight gain or if the TZD (pioglitazone) is contraindicated [5].

The American Diabetes Association (ADA) and the European Association for the Study of Diabetes (EASD), in their updated guideline (2015), suggest TZDs and gliptins as second-line therapy strategies if metformin is not sufficient for achieving a satisfying $\mathrm{HbA}_{1 \mathrm{c}}$ level [6].

Other strategies offered by both guidelines include glucagon-like peptide-1 receptor agonists, sodium glucose co transporter-2 inhibitors, sulphonylureas, insu$\operatorname{lin}[5,6]$.

Gliptins (sitagliptin, vildagliptin) in combination with metformin are predominantly used in therapeutic practice in Bulgaria. Sales of sitagliptin/metformin for 2014 in the country amounted to BGN 13 million (EUR 6,646,794), and of vildaglliptin/metfomin - to BGN 12.5 million (EUR $6,391,149$ ) according to IMS (Intercontinental Marketing Services) Health. Sales of pioglitazone were BGN 0.1 million (EUR 51,129).

The established disproportion in sales is due to the different levels of reimbursement of medicinal products - sitagliptin - $100 \%$, vildagliptin - $100 \%$, pioglitazone - $25 \%$, sitagliptin/metformin - $50 \%$, vildaglliptin/metfomin - $50 \%$. Decisions for the inclusion of drugs in the Positive Drug List (PDL) and determination of the levels of reimbursement are made by the National Council on Prices and Reimbursement of Medicinal Products (NCPRMP).

This is a comparative analysis of the efficacy, safety and costs of oral antidiabetic therapies based on gliptins and glitazones, aiming to assess the objectivity of the decisions concerning pricing and reimbursement based on pharmacoeconomic evidence presented by the pharmaceutical industry.

A search of PubMed, Medline, Sciencedirect, Food and Drug Administration (FDA), European Medicines Agency (EMA), NCPRMP websites was performed with the following keywords: TZDs, pioglitazone, DPP-4 inhibitors, gliptins, sitagliptin, vildagliptin, metformin, efficacy, safety, adverse reactions, and combination therapy. Original articles and reviews as well as abstracts discussing the efficacy and safety of pioglitazone, sitagliptin and vildagliptin mono- or combination therapy, published in the 2000-2015 period were included in the current review.

\section{Review}

\section{Efficacy of pioglitazone}

TZDs favorably influence upon the majority of the components of insulin resistance characteristic of T2DM, like adiposity, dyslipidaemia, hyperglycaemia, hypertension, cardiovascular abnormalities, hyper coagulation, vasculopathy, accelerated atherosclerosis, and changes in liver and ovaries [7]. TZDs, pioglitazone in particular, successfully reduce $\mathrm{HbA}_{1 \mathrm{c}}$ (Table 1 ). Studies have shown decrease in $\mathrm{HbA}_{1 \mathrm{c}}$ of $0.92 \%$ and $1.05 \%$ compared to placebo for pioglitazone $15 \mathrm{mg}$ and $30 \mathrm{mg}$, respectively $[8,9]$ and some authors even report values of $2 \%$ [4]. When this parameter is considered, the hypoglycemic profile of pioglitazone resembles that of sulphonylurea and metformin unlike the gliptins for which some authors indicate a reduction of $\mathrm{HbA}_{1 \mathrm{c}}$ of $0.7 \%$ to $0.9 \%$ for

Table 1 Comparative table of clinical trials investigating the efficacy of therapies based on glitazones and gliptins versus placebo

\begin{tabular}{|c|c|c|c|c|c|c|}
\hline \multirow[t]{2}{*}{ Reference } & \multirow[t]{2}{*}{$\mathrm{N}$} & \multirow[t]{2}{*}{ Treatment } & \multirow{2}{*}{$\begin{array}{l}\text { Baseline values for } \\
\mathrm{HbA}_{1 c}[\%]\end{array}$} & \multicolumn{2}{|l|}{ Results } & \multirow{2}{*}{$\begin{array}{l}\text { Statistical } \\
\text { significance }\end{array}$} \\
\hline & & & & $\begin{array}{l}\text { Glycated hemoglobin } \\
\mathrm{HbA}_{1 c}[\%]\end{array}$ & $\begin{array}{l}\text { Fasting plasma glucose } \\
\text { (FPG) }[\mathrm{mmol} / \mathrm{L}]\end{array}$ & \\
\hline \multirow[t]{2}{*}{ Lü et al., 2011 [8] } & 236 & $S U+P L B$ & In the range of 7.0 to 12.0 & $-0.28 \pm 0.11$ & $+0.17 \pm 1.92$ & SS \\
\hline & & SU + PIO 30 mg & & $-0.92 \pm 0.10$ & $-1.48 \pm 2.08$ & $p<0.05$ \\
\hline \multirow[t]{3}{*}{ Scherbaum et al., 2002 [9] } & 84 & PLB + diet & & & & SS \\
\hline & 89 & PIO 15 mg + diet & & -0.92 & -1.9 & \\
\hline & 78 & PIO 30 mg + diet & & -1.05 & -2.0 & \\
\hline \multirow[t]{2}{*}{ Yang et al., 2012 [10] } & 395 & $\mathrm{MET}+\mathrm{PLB}$ & 8.5 & & & SS \\
\hline & & $\mathrm{MET}+\mathrm{SIT}$ & & -0.9 & -1.2 & $p<0.001$ \\
\hline \multirow[t]{2}{*}{ Barzilai et al., 2011 [11] } & 206 & PLB & 7.8 & & & SS \\
\hline & & SIT 50 (100) mg & & -0.7 & -1.5 & $p<0.001$ \\
\hline \multirow[t]{2}{*}{ Yang et al., 2015 [12] } & 136 & $S U+P L B$ & 8.6 & -0.2 & & SS \\
\hline & 143 & SU + VIL 100 mg & 8.7 & -0.7 & & $p<0.001$ \\
\hline \multirow[t]{2}{*}{ Lukashevich et al., 2014 [15] } & 160 & PLB + MET + glimepiride & 8.80 & -0.25 & +0.02 & SS \\
\hline & 158 & VIL + MET + glimepiride & 8.75 & -1.01 & -1.11 & $p<0.001$ \\
\hline
\end{tabular}


sitagliptin [10, 11] and around $0.7 \%$ for vildagliptin [12] in comparison with placebo. Other authors claim that sitagliptin and vildagliptin provide similar improvements in $\mathrm{HbA}_{1 \mathrm{c}}$ levels when compared with metformin, sulfonylureas or glitazones without contributing to weight gain and hypoglycemia [13] with reductions of $\mathrm{HbA}_{1 \mathrm{c}}$ of up to $-1.0 \%$ for sitagliptin and $0.9 \%$ for vildagliptin [14].

It appears that TZDs reduce fasting plasma glucose (FPG) as well. Lü et al. have shown that pioglitazone is more effective in decreasing FPG when compared to placebo - - $1.48 \mathrm{mmol} / \mathrm{L}$ versus control group [8]. The reduction in comparison with placebo was $1.2 \mathrm{mmol} / \mathrm{L}$ [10] for sitagliptin and $1.11 \mathrm{mmol} / \mathrm{L}$ [15] for vildagliptin, respectively.

Results from trials conducted on both humans and animals have shown that TZDs preserve $\beta$-cell function, increase high-density lipoprotein (HDL) cholesterol and low-density lipoprotein (LDL) cholesterol with 10 to $15 \%$ [16] and decrease triglyceride levels with the latter effect being more pronounced in the case of pioglitazone [4]. Some studies suggested that gliptins improve lipid parameters as well, with vildagliptin having a more beneficial effect on the lipid profile than sitagliptin [17].

\section{Efficacy of monotherapy with pioglitazone compared to monotherapy with sitagliptin and vildagliptin}

The clinical trial DURATION-4 [18], which enrolled 820 subjects (696 completed all 26 weeks of therapy) aimed to monitor and assess the effectiveness of exenatide, metformin, pioglitazone and sitagliptin in patients with T2DM. The authors reported decrease in $\mathrm{HbA}_{1 \mathrm{c}}$ of $1.63 \%$ in the pioglitazone group compared to $1.15 \%$ in the sitagliptin group. The average value of $\mathrm{HbA}_{1 \mathrm{c}}$ at the end of the study was the lowest in the pioglitazone group- $6.84 \%$ for pioglitazone and $7.32 \%$ to sitagliptin. The data was statistically significant and showed the notably greater effect of TZDs on the glycemic profile of patients. When FPG reduction was taken into account pioglitazone proved to be more efficient:- $2.6 \mathrm{mmol} / \mathrm{L}$ for pioglitazone;-1.1 $\mathrm{mmol} / \mathrm{L}$ for sitagliptin. Both drugs had a similar effect on the function of $\beta$-cells, but pioglitazone significantly improved insulin sensitivity compared to sitagliptin as measured by geometric mean HOMA-S (ratio of end point [last observation carried forward] to baseline): $[+1.5(0,06)]$ for pioglitazone and $[+1.0(0,04)]$ for sitagliptin.

Rosenstock et al. compared monotherapy with pioglitazone and monotherapy with vildagliptin and reported significantly greater effectiveness for pioglitazone. It reduced $\mathrm{HbA}_{1 \mathrm{c}}(1.4 \pm 0.1 \%$ reduction for monotherapy with pioglitazone versus $1.1 \pm 0.1 \%$ for vildagliptin) and FPG $(1.9 \pm 0.2 \mathrm{mmol} / \mathrm{L}$ reduction for pioglitazone versus $1.3 \pm 0.2 \mathrm{mmol} / \mathrm{L}$ for vildagliptin) to a greater extent than the gliptins [19].
Pérez-Monteverde et al. reported results from a randomized double-blind trial comparing the efficacy of sitagliptin and pioglitazone monotherapy. Reductions in $\mathrm{HbA}_{1 \mathrm{c}}$ were similar in both groups $--1.0 \%$ and $-0.9 \%$ for sitagliptin and pioglitazone, respectively. Both therapies reduced FPG similarly:- $1.48 \mathrm{mmol} / \mathrm{L}$ and $-1.56 \mathrm{mmol} / \mathrm{L}$ for sitagliptin and pioglitazone, respectively. It should be noted that while sitagliptin was given in its maximum recommended dose of $100 \mathrm{mg}$ from the very beginning, pioglitazone was not - patients received $15 \mathrm{mg}$ which were only later titrated to $30 \mathrm{mg}$ [20] (Table 2).

Reported data has indicated that the probability of reaching target $\mathrm{HbA}_{1 \mathrm{c}}<7 \%$ is higher in the case of therapy with pioglitazone [21].

\section{The efficacy of combination therapy pioglitazone + metformin as compared to the combination therapies sitagliptin + metformin and vildagliptin + metformin}

Few therapeutic agents for the treatment of T2DM address both insulin resistance and $\beta$-cell function when administered as monotherapy. Pioglitazone and metformin increase insulin sensitivity and improve $\beta$-cell function, with TZDs having a more prominent effect on $\beta$-cells. These characteristics of the two drugs make their combination suitable either as initial therapy, or as very rapid add-on therapy for patients who do not achieve target glycemic control [22]. At the same time, gliptins (sitagliptin, vildagliptin) do not influence insulin resistance [23]. In preclinical studies, DPP-4 inhibitors have been shown to promote $\beta$-cell proliferation but there is no clinical evidence yet of the protective effects of incretin enhancers on $\beta$-cells in humans [24].

When comparing the combined therapy with pioglitazone and metformin with a combination of sitagliptin and metformin, a number of studies have demonstrated the advantage of combining the hypoglycaemic effects of metformin with those of TZDs (Table 2). Chawla et al. reported changes in levels of $\mathrm{HbA}_{1 \mathrm{c}}$ from baseline for sitagliptin (group 1) $-0.656 \pm 0.21 \%$ and $-0.748 \pm 0.35 \%$ for pioglitazone (group 2). After 16 weeks, the mean reductions in FPG were $1.09 \mathrm{mmol} / \mathrm{L}$ and $1.69 \mathrm{mmol} / \mathrm{L}$, respectively, for group 1 and 2 [25]. In a randomized openlabel study, Liu et al. observed mean change in $\mathrm{HbA}_{1 \mathrm{c}}$ from baseline- $0.94 \pm 0.12 \%$ with pioglitazone and $-0.71 \pm$ $0.12 \%$ with sitagliptin, which again confirmed the positive effect of TZDs. The mean change in FPG were-1.98 \pm $0.22 \mathrm{mmol} / \mathrm{L}$ with pioglitazone and $-1.27 \pm 0.22 \mathrm{mmol} / \mathrm{L}$ with sitagliptin, with a difference between the two groups of $-0.72 \pm 0.32 \mathrm{mmol} / \mathrm{L}(P=0.02)$ [26]. Bergenstal et al. compared the glycemic effect of pioglitazone and sitagliptin as adjunctive therapy to metformin in patients with T2DM in the study DURATION-2. Both therapies led to reduced levels of $\mathrm{HbA}_{1 \mathrm{c}}$, but it was more pronounced in the combination of pioglitazone and metformin: sitagliptin $(-0.9 \%, 95 \%$ CI-1.1 to-0.7) 
Table 2 Comparative table of clinical trials investigating the efficacy of therapies based on glitazones versus gliptins

\begin{tabular}{|c|c|c|c|c|c|c|}
\hline \multirow[t]{2}{*}{ Reference } & \multirow[t]{2}{*}{$N$} & \multirow[t]{2}{*}{ Treatment } & \multirow{2}{*}{$\begin{array}{l}\text { Baseline values for } \\
\mathrm{HbA}_{1 \mathrm{c}}[\%]\end{array}$} & \multicolumn{2}{|l|}{ Results } & \multirow[t]{2}{*}{ Statistical significance } \\
\hline & & & & $\begin{array}{l}\text { Glycated hemoglobin } \\
\mathrm{HbA}_{1 c}[\%]\end{array}$ & $\begin{array}{l}\text { Fasting plasma glucose } \\
\text { (FPG) }[\mathrm{mmol} / \mathrm{L}]\end{array}$ & \\
\hline \multirow{2}{*}{$\begin{array}{l}\text { Pérez-Monteverde et al., } \\
2011 \text { [20] }\end{array}$} & \multirow[t]{2}{*}{492} & SIT $100 \mathrm{mg}$ & & -1.0 & -1.48 & \\
\hline & & $\begin{array}{l}\text { PIO } 15 \mathrm{mg} \\
(30 \mathrm{mg})\end{array}$ & & -0.9 & -1.56 & \\
\hline \multirow{4}{*}{$\begin{array}{l}\text { Russell-Jones et al., } \\
2012 \text { [18] }\end{array}$} & 248 & EQW 2 mg & \multirow{4}{*}{$\begin{array}{l}\text { Ranging from } 8.0 \text { to } \\
8.6 \text { across treatment } \\
\text { groups }\end{array}$} & -1.53 & -2.3 & \multirow[t]{2}{*}{ SS } \\
\hline & 246 & MET 2000 mg & & -1.48 & -2.0 & \\
\hline & 163 & $\mathrm{PIO} 45 \mathrm{mg}$ & & -1.63 & -2.6 & \multirow[t]{2}{*}{$p<0.001$} \\
\hline & 163 & SIT $100 \mathrm{mg}$ & & -1.15 & -1.1 & \\
\hline \multirow[t]{4}{*}{ Rosenstock et al., 2007 [19] } & 161 & $\mathrm{PIO} 30 \mathrm{mg}$ & $8.7 \pm 1.0$ & $-1.4 \pm 0.1$ & $-1.9 \pm 0.2$ & \multirow[t]{2}{*}{ SS } \\
\hline & 154 & VIL 100 mg & $8.6 \pm 1.0$ & $-1.1 \pm 0.1$ & $-1.3 \pm 0.2$ & \\
\hline & 144 & $\mathrm{PIO}+\mathrm{VIL}$ 15/50 mg & $8.8 \pm 0.9$ & $-1.7 \pm 0.1$ & $-2.4 \pm 0.2$ & \multirow[t]{2}{*}{$p<0.001$} \\
\hline & 148 & $\mathrm{PIO}+\mathrm{VIL} 30 / 100 \mathrm{mg}$ & $8.8 \pm 0.9$ & $-1.9 \pm 0.1$ & $-2.8 \pm 0.2$ & \\
\hline \multirow[t]{2}{*}{ Chawla et al., 2013 [25] } & \multirow[t]{2}{*}{52} & SIT + MET 100/>1500 mg & $8.076 \pm 0.722$ & $-0.656 \pm 0.21$ & -1.1 & \multirow{2}{*}{$\begin{array}{l}\text { NS } P=0.268 \text { for the } \\
\text { between group } \\
\text { difference }\end{array}$} \\
\hline & & $\mathrm{PIO}+\mathrm{MET} 30 />1500 \mathrm{mg}$ & $8.228 \pm 0.822$ & $-0.748 \pm 0.35$ & -1.7 & \\
\hline \multirow[t]{2}{*}{ Liu et al., 2013 [26] } & 60 & $\begin{array}{l}\mathrm{SIT}+\mathrm{MET}+\mathrm{SU} 100 / \geq 1500 / \\
\text { half maximal dose }\end{array}$ & & $-0.71 \pm 0.12$ & $-1.27 \pm 0.22$ & \multirow{2}{*}{$\begin{array}{l}\text { NS } p=0.16 \text { between } \\
\text { group difference } \\
\text { for } \mathrm{HbA}_{1 c}\end{array}$} \\
\hline & 59 & $\begin{array}{l}\mathrm{PIO}+\mathrm{MET}+\mathrm{SU} 30 / \geq 1500 / \\
\text { half maximal dose }\end{array}$ & & $-0.94 \pm 0.12$ & $-1.98 \pm 0.22$ & \\
\hline \multirow[t]{3}{*}{ Bergenstal et al., 2010 [27] } & 170 & EQW $2 \mathrm{mg}+\mathrm{MET}$ & 8.5 & -1.5 & & \multirow{3}{*}{$\begin{array}{l}\text { SS } p<0.0001 \text { for } \\
\text { EQW vs. SIT; } p=0.0165 \\
\text { for EQW vs. PIO }\end{array}$} \\
\hline & 172 & $\mathrm{PIO} 45$ mg + MET & & -1.2 & & \\
\hline & 172 & SIT $100 \mathrm{mg}+\mathrm{MET}$ & & -0.9 & & \\
\hline \multirow[t]{3}{*}{ Lee et al., 2013 [28] } & 31 & $\begin{array}{l}\text { MET + gliclazide or } \\
\text { glimepiride }\end{array}$ & 8.9 & -2.5 & From 9.24 to 5.71 & \multirow{3}{*}{$\begin{array}{l}\mathrm{SS} p<0.001 \text { for difference } \\
\text { in } \mathrm{HbA}_{1} \text { from baseline } \\
\text { for all groups }\end{array}$} \\
\hline & 30 & $\mathrm{MET}+\mathrm{PIO} 15 \mathrm{mg}$ & 8.8 & -2.8 & From 9.66 to 6.16 & \\
\hline & 38 & $\mathrm{MET}+\mathrm{SIT} 100 \mathrm{mg}$ & 9.4 & -2.7 & From 9.60 to 5.86 & \\
\hline \multirow[t]{2}{*}{ Blonde et al., 2009 [29] } & 1653 & $\mathrm{MET}+\mathrm{VIL} \geq 1000 / 100 \mathrm{mg}$ & & $-0.68 \pm 0.02$ & & SS \\
\hline & 825 & $\mathrm{MET}+\mathrm{TZDs} \geq 1000 \mathrm{mg}$ & & $-0.57 \pm 0.03$ & & $p=0.001$ \\
\hline \multirow{2}{*}{$\begin{array}{l}\text { Bolli et al., 2008, } 2009 \\
{[30,31]}\end{array}$} & 295 & $\mathrm{MET}+\mathrm{VIL}>1500 / 100 \mathrm{mg}$ & $8.4 \pm 1.0$ & $-0.88 \pm 0.5$ & $-1.4 \pm 0.1$ & SS \\
\hline & 281 & $\mathrm{MET}+\mathrm{PIO}>1500 / 30 \mathrm{mg}$ & $8.4 \pm 0.9$ & $-0.98 \pm 0.06$ & $-2.1 \pm 0.1$ & $\begin{array}{l}p<0.001 \text { for all treatment } \\
\text { groups at week } 52 \text { vs. baseline }\end{array}$ \\
\hline \multirow[t]{3}{*}{ Kaur M. et al., 2014 [32] } & 30 & $\mathrm{MET}+\mathrm{VIL}$ 500/50 mg & $8.43 \pm 0.75$ & -0.75 & -1.75 & SS \\
\hline & 30 & $\mathrm{MET}+\mathrm{PIO} 500 / 15 \mathrm{mg}$ & $8.55 \pm 0.84$ & -0.85 & -1.85 & \multirow{2}{*}{$\begin{array}{l}p<0.001 \text { for all treatment } \\
\text { groups vs. baseline }\end{array}$} \\
\hline & 30 & VIL + PIO 50/15 mg & $8.56 \pm 0.69$ & -1.35 & -2.6 & \\
\hline
\end{tabular}


Table 2 Comparative table of clinical trials investigating the efficacy of therapies based on glitazones versus gliptins (Continued)

\begin{tabular}{|c|c|c|c|c|c|c|}
\hline \multirow[t]{2}{*}{ Jindal et al., 2015 [1] } & 30 & MET + PIO 1000/30 mg & & \multirow{2}{*}{$\begin{array}{l}\text { No values, the authors } \\
\text { comment that there are } \\
\text { not statistically } \\
\text { significant differences in } \\
\text { the reduction of } \mathrm{HbA}_{1 c} \\
\text { between the two groups }\end{array}$} & \multirow[b]{2}{*}{$\begin{array}{l}\text { No values, the authors } \\
\text { comment that there } \\
\text { are not } \\
\text { statistically significant } \\
\text { differences in the reduction } \\
\text { of FPG between } \\
\text { the two } \\
\text { groups }\end{array}$} & SS \\
\hline & 30 & MET + VIL 1000/100 mg & & & & $\begin{array}{l}p<0.001 \text { for all treatment } \\
\text { groups vs. baseline }\end{array}$ \\
\hline \multirow[t]{2}{*}{ Kaur K. et al., 2014 [33] } & 25 & $\mathrm{PIO} 30 \mathrm{mg}+\mathrm{MET}+\mathrm{SU}$ & $10.93 \pm 2.9$ & -1.65 & -2.83 & SS \\
\hline & 25 & $\mathrm{VIL} 50 \mathrm{mg}+\mathrm{MET}+\mathrm{SU}$ & $11.3 \pm 0.6$ & -1.23 & -3.35 & $\begin{array}{l}p<0.001 \text { for all } \\
\text { treatment } \\
\text { groups vs. baseline }\end{array}$ \\
\hline
\end{tabular}

EQW exenatide, MET metformin, PIO pioglitazone, SIT sitagliptin, VIL vildagliptin, SU sulphonylurea, TZDs Thiazolidinediones, PLB placebo, SS statistically singnificant, SN statistically non-significant 
and pioglitazone $(-1.2 \%, 95 \%$ CI-1.4 to-1.0) [27]. Lee et al. have concluded that dual therapies using combinations of metformin and pioglitazone or sitagliptin show similar glycemic efficacy among patients with T2DM [28]. The percentage of reduction in $\mathrm{HbA}_{1 \mathrm{c}}$, observed by the authors has confirmed this statement $(-2.8 \%$ for pioglitazone with metformin;-2.7 \% for sitagliptin with metformin), but it should be noted that while sitagliptin was taken at the maximum recommended dose of $100 \mathrm{mg}$, pioglitazone was not - patients received $15 \mathrm{mg}$ while the maximum recommended dose is $45 \mathrm{mg}$.

The randomized, open-label, comparative study GALIANT, which assessed the effectiveness of treatment with vildagliptin compared to TZDs as adjunctive therapy to metformin ( $\geq 1000 \mathrm{mg} /$ day) in patients with T2DM, showed that changes in $\mathrm{HbA}_{1 \mathrm{c}}$ levels in the two groups did not differ significantly. The authors concluded that the efficacy of both combination therapies is similar [29]. At the same time Bolli et al. found that pioglitazone in addition to metformin, is superior to vildagliptin + metfor$\mathrm{min}$, as it leads to significant reductions in $\mathrm{HbA}_{1 \mathrm{c}}(-0.98 \pm$ $0.06 \%)$ and FPG $(-2.1 \pm 0.1 \mathrm{mmol} / \mathrm{L})$. In comparison, the values obtained for these parameters in the group treated with vildagliptin were- $0.88 \pm 0.5 \%$ and $-1.4 \pm 0.1 \mathrm{mmol} / \mathrm{L}$, respectively [30, 31]. The objective of a prospective, open, randomized, parallel study involving 90 patients was to determine the effectiveness and safety of three combinations of antihyperglycemic agents - metformin + pioglitazone; vildagliptin + metformin; vildagliptin + pioglitazone. After 12 weeks of therapy, $\mathrm{HbA}_{1 \mathrm{c}}$ fell by $0.85 \%$ for metformin + pioglitazone and by $0.75 \%$ for vildagliptin + metformin. A greater reduction of FPG was also reported in the group treated with pioglitazone. Significant reduction of insulin resistance was observed in all three groups, but when comparing metformin + pioglitazone and vildagliptin + metformin, the advantage was again in favor of the TZDs - 28.75 $\%$ against $18.76 \%$ for the gliptins [32]. A recent (2015) multicenter, open label, randomized, parallel study comparing the effectiveness of vildagliptin and pioglitazone in combination with metformin, has shown that both drugs have similar efficacy in improving glycemic control in patients with T2DM for 24 weeks. There is a significant decrease in FPG in both groups. There are no statistically significant differences in the reduced levels of $\mathrm{HbA}_{1 \mathrm{c}}$ after 12 and 24 weeks between the two groups. Improvements in glycemic control influence favorably $\beta$-cell function in both groups [1]. When comparing triple therapies with metformin, sulphonylurea and pioglitazone or vildagliptin, Kaur et al. reported a significant decrease in $\mathrm{HbA}_{1 \mathrm{c}}$ in the TZDs group:-1.65 \% in the comparison with-1.23 \% for vildagliptin [33].

Results have indicated that the combination therapy with pioglitazone + metformin is more effective than sitagliptin + metformin, while the comparison with vildagliptin + metformin has shown that the two treatment regimens have similar efficacy.

\section{Safety of pioglitazone}

T2DM is serious, chronic, progressive and widespread disease. In patients with T2DM, the risk of macrovascular complications (coronary artery disease, peripheral arterial disease, stroke) and microvascular complications (diabetic nephropathy, neuropathy and retinopathy) is high. In most of these patients metabolic disorders are observed, which themselves are significant risk factors. It is believed that the increased risk of cardiovascular complications is due to not only but also to lipid disorders, hypertension, chronic vascular inflammation and overall state of susceptibility to atherothrombosis in patients with diabetes. Patients with T2DM have an increased risk of fragility fractures despite increased body weight and normal or higher bone mineral density.

It is known that the efficiency of pioglitazone is associated with the implementation of good glycemic control and improvement of insulin sensitivity on the one hand; on the other hand it improves dyslipidemia, hypertension and microalbuminuria in patients with T2DM. Some studies have shown that pioglitazone increases the levels of HDL cholesterol and reduces the levels of triglyceride, fasting plasma free fatty acids, without affecting the levels of total cholesterol and LDL cholesterol [34, 35]. As specific agonists of the PPAR- $\gamma$, TZDs reduce the levels of circulating pro-inflammatory biomarkers of atherosclerosis [36], moreover, in patients treated with pioglitazone significantly lower rate of progression of coronary atherosclerosis was observed [37]. The effect of TZDs was associated with increased levels of adiponectin (vascular protective adipokine) and reduced levels of tissue necrosis factor $\alpha$, which in turn leads to a decreased risk of cardiovascular complications. TZDs exert beneficial effect on coronary and peripheral vasodilation, with minimal improvement of blood pressure. Small controlled studies, using surrogate markers such as the intima-media thickness of the carotid artery, have shown improvements in patients treated with TZDs [38]. Protective effect against restenosis after percutaneous intervention in TZDs treated patients was also indicated [39, 40]. During the Duration-4 trial significant changes in serum lipids were not observed. The decrease in systolic blood pressure were:-1.3 $\mathrm{mmHg}(0.8$ $\mathrm{mmHg}),-1.7 \mathrm{mmHg}$ (1.0 $\mathrm{mmHg})$, and $-1.8 \mathrm{mmHg}$ (1.0 $\mathrm{mmHg}$ ) in therapy with exenatide, pioglitazone and sitagliptin, respectively. Reduction in diastolic blood pressure is achieved only on therapy with pioglitazone:-2.5 $\mathrm{mmHg}$ (0.6 mmHg). Compared with other drugs pioglitazone decreased heart rate [18].

ACT NOW study (for the prevention of diabetes) shows that pioglitazone leads to a reduction of the risk of 
developing of T2DM by $70 \%$ in addition to ensuring stable glycemic control in these patients [41].

In contrast to the aforementioned benefits, the TZDs, in particular pioglitazone increased body weight (Table 3) $[1,18,19,25,31]$, in part because of differentiation of adipocytes and expansion of adipocyte mass. Activation of PPAR- $\gamma$ stimulates differentiation to insulin-sensitive smaller adipocytes and redistributes fat from visceral to subcutaneous depots, a pattern that has been associated with lower cardiovascular disease (CVD) risk. On the other hand, DPP-4 inhibitors have generally neutral effect on weight $[1,23,31]$. It was found out that there was no weight gain with any DPP-4 inhibitors [SAXA: 0.06 (95\% CI-0.45, 0.57) SIT: 0.21 (95\% CI-0.1, 0.53) VIL: 0.04 (95 \% CI-0.37, 0.44)], but TZDs were associated with significant increases in body weight [PIO: 2.06 (95\% CI 1.31, 2.81)] in a recent random-effects network meta-analysis, which included 62 randomized clinical trials $(\mathrm{n}=32185$ participants) [42].

New or worsening peripheral edema is common with TZD use, ranging from $2.5 \%$ to $16.2 \%$ incidence, with risk increasing with age, increasing drug dose, female sex, declining renal function, and concomitant insulin use $[39,40]$. Typical, but manageable, increases in oedema ( $26.4 \%$ vs $15.1 \%$ for placebo) and weight gain (mean change of $+3.8 \mathrm{~kg}$ vs- $0.6 \mathrm{~kg}$ for placebo) associated with pioglitazone therapy in PROactive were reviewed by Dormandy et al. [43].

Current drug labels for TZDs warn of increased fractures, predominantly for distal fractures in women [44-46]. A higher rate of bone fractures was observed among pioglitazone-treated female patients $(5.1 \%$ vs $2.5 \%)$ in PROactive study population [43]. Moreover, a randomized, placebo-controlled trial demonstrated that pioglitazone treatment was followed by decreased lumbar and hip bone mineral density (BMD) and decreased measures of bone turnover in premenopausal patients with polycystic ovary syndrome [47]. The findings of a large, population-based, nested, case-control analysis have provided further evidence that current use of rosiglitazone and pioglitazone in women and men with T2DM may be associated with an approximately 2- to 3fold increased risk of hip and nonvertebral osteoporotic fractures [48]. Colhoun et al. observed hip fractures in both sexes and the risk was similar for pioglitazone users and rosiglitazone users [49]. Furthermore, not all studies have demonstrated such an increase in risk. According to Bazelier et al., risk of osteoporotic fracture was similar for TZD users and insulin users, but versus nondiabetic patients TZD users showed a 1.3-fold increased risk of fracture. In their opinion the underlying T2DM should be taken into account, when studying fracture risk with TZDs [46]. The results of a prospective, double-blind study did not demonstrate a causal relationship between pioglitazone treatment for 12 months and loss of bone mass or alteration of bone remodeling that would be expected to result in excessive bone fragility [50]. The effect of TZDs on bone is a drug class effect and duration of treatment is proportional with increased fracture risk [51]. Preclinical studies have suggested that incretin-based therapies may be beneficial for the bone; however, clinical data are largely lacking. A meta analysis performed by Monami et al. on all trials that enrolled T2DM patients that received DPP-4 inhibitors for at least 24 weeks suggested that DPP-4 inhibitors could be associated with reduced risk of bone fracture [52], but the duration of included trials was short and bone fracture were not the principal end points in any of the studies and were reported only as adverse events, and were probably not described carefully. A neutral role of DPP-4 inhibitors on bone metabolism was demonstrated by treatment with vildagliptin (100 mg once daily) in drug naïve type 2 diabetic patients for 1 year. Circulating levels of markers of bone resorption (cross-linked C-terminal telopeptide) and calcium homeostasis (serum alkaline phosphatase, calcium, and phosphate) were unaffected compared to baseline and to placebo [53]. However, clinical evidence for DPP-4 inhibitors in humans is still not enough to allow definitive conclusions and further studies are required for their long-term efficacy and safety on bone metabolism.

Pioglitazone carries black box label warnings about its potential to cause or exacerbate congestive heart failure and is contraindicated in patients with New York Heart Association class III or IV heart failure (HF) [54]. Pioglitazone is the only hypoglycemic drug, other than metformin, with conducted randomized trial which has clearly demonstrated that it reduces mortality, myocardial infarction and stroke. PROactive is a large, prospective, randomized, double-blind study that examined the effect of pioglitazone $(45 \mathrm{mg}$

/day) on macrovascular complications in 5238 patients with T2DM and concomitant cardiovascular diseases. The study showed that pioglitazone non-significantly reduces $(10 \%)$ the risk of the composite primary endpoint - death from any cause, non-fatal myocardial infarction (including silent myocardial infarction), stroke, acute coronary syndrome, leg amputation, coronary revascularisation, or revascularisation of the leg. The pre-defined main secondary endpoint-all-cause mortality, myocardial infarction, or stroke-was also significantly reduced, in the pioglitazone group. Despite the increase in reported heart failure in the pioglitazone group, the number of deaths from heart failure was similar in each group [55].

Pioglitazone is beneficial in reducing the chances of a patient who has had a stroke from having further stroke. A subgroup analysis from PROactive study found that pioglitazone reduced the occurrence of fatal or non-fatal stroke $(5.6 \%$ in the pioglitazone group against $10.2 \%$ in the placebo group) and mortality due to cardiovascular 
Table 3 Comparative table of clinical trials and studies, investigating the safety of treatment with gliptins and glitazones

\begin{tabular}{|c|c|c|}
\hline Author & Treatment & Change in mean body weight \\
\hline \multirow[t]{2}{*}{ Bolli et al., 2009 [31] } & $\mathrm{VIL}+\mathrm{MET}$ & $\uparrow 0.2 \mathrm{~kg}$, non-significant \\
\hline & $\mathrm{PIO}+\mathrm{MET}$ & $\uparrow 2.6 \mathrm{~kg}, P<0.001$ \\
\hline \multirow[t]{2}{*}{ Jindal et al., 2015 [1] } & $\mathrm{VIL}+\mathrm{MET}$ & No change in body weight \\
\hline & $\mathrm{PIO}+\mathrm{MET}$ & $\uparrow 1.2 \pm 0.5 \mathrm{~kg}$ \\
\hline \multirow[t]{2}{*}{ Chawla et al., 2013 [25] } & $\mathrm{SIT}+\mathrm{MET}$ & $\downarrow 0.58 \mathrm{~kg}$, statistically significant \\
\hline & $\mathrm{PIO}+\mathrm{MET}$ & $\uparrow 0.90 \mathrm{~kg}$, statistically significant \\
\hline \multirow[t]{4}{*}{ Russell-Jones et al., 2012 [18] } & EQW & $\downarrow 2.0 \mathrm{~kg}$ \\
\hline & MET & $\downarrow 2.0 \mathrm{~kg}(P=0.892$ vs. EQW $)$ \\
\hline & $\mathrm{PIO}$ & $\uparrow 1.5 \mathrm{~kg}(P<0.001$ vs. EQW $)$ \\
\hline & SIT & $\downarrow 0.8 \mathrm{~kg}(P<0.001$ vs. EQW $)$ \\
\hline \multirow[t]{5}{*}{ Rosenstock et al., 2007 [19] } & VIL & $\uparrow 0.2 \pm 0.3 \mathrm{~kg}$ \\
\hline & $\mathrm{PIO}$ & $\uparrow 1.5 \pm 0.3 \mathrm{~kg}$ \\
\hline & $\mathrm{VIL}+\mathrm{PIO}(50 / 15 \mathrm{mg})$ & $\uparrow 1.4 \pm 0.3 \mathrm{~kg}$ \\
\hline & $\mathrm{VIL}+\mathrm{PIO}(100 / 30 \mathrm{mg})$ & $\uparrow 2.1 \pm 0.3 \mathrm{~kg}$ \\
\hline & & Risk of fractures \\
\hline \multirow[t]{4}{*}{ Bone et al., 2013 [50] } & $\mathrm{PIO}$ & BMD of total proximal femur (primary and point): \\
\hline & PLB & $\begin{array}{l}\text { Least squares mean from baseline: }-0.69 \% \text { PIO, }-0.14 \% \text { PLB }(P=0.170) \\
\text { statistically non-significant }\end{array}$ \\
\hline & & Bone remodeling markers: \\
\hline & & statistically non-significant between-group differences \\
\hline \multirow[t]{4}{*}{ Bazelier et al., 2012 [46] } & Biguanide or Sulfonyluerum & $\downarrow$ risk $\mathrm{HR}=1.15,95 \% \mathrm{Cl} 1.13-1.18$ \\
\hline & Biguanide and Sulfonyluerum & $\downarrow$ risk $\mathrm{HR}=1.00,95 \% \mathrm{Cl} 0.96-1.04$ \\
\hline & TZDs & $\uparrow$ risk $\mathrm{HR}=1.27,95 \% \mathrm{Cl} 1.06-1.52$ \\
\hline & Insulin & $\uparrow$ risk $\mathrm{HR}=1.25,95 \% \mathrm{Cl} 1.20-1.31$ \\
\hline \multirow[t]{2}{*}{ Glintborg et al., 2008 [47] } & $\mathrm{PIO}$ & \multirow{2}{*}{$\begin{array}{l}\downarrow \mathrm{BMD} \text { [geometric means }\left(-2 \text { to }+2_{\mathrm{SD}}\right) \text { : lumbar spine } 1.140(0.964-1.348) \text { vs. } \\
\left.1.127(0.948-1.341) \mathrm{g} / \mathrm{cm}^{2} \text { (average decline } 1.1 \%\right) \text { and femoral neck } 0.966 \\
\left.(0.767-1.217) \text { vs. } 0.952(0.760-1.192) \mathrm{g} / \mathrm{cm}^{2} \text { (average decline } 1.4 \%\right) \text {, both } p<0.05 \text { ] }\end{array}$} \\
\hline & PLB & \\
\hline \multirow[t]{2}{*}{ Meier et al., 2008 [48] } & $\mathrm{PIO}$ & $\uparrow$ hip and nonvertebral osteoporotic fractures $\mathrm{OR}=2.59,95 \% \mathrm{Cl} 0.96-7.01$ \\
\hline & ROSI & $\uparrow$ hip and nonvertebral osteoporotic fractures OR $=2.38,95 \% \mathrm{Cl} 1.39-4.09$ \\
\hline \multirow[t]{2}{*}{ Colhoun et al., 2012 [49] } & $\mathrm{PIO}$ & $\uparrow$ hip fractures risk OR $=1.18,95 \% \mathrm{Cl} 1.00-1.40$ \\
\hline & ROSI & $\uparrow$ hip fractures risk OR $=1.16,95 \% \mathrm{Cl} 1.06-1.26$ \\
\hline \multirow[t]{2}{*}{ Bunck et al., 2012 [53] } & $\mathrm{VIL}$ & \multirow{2}{*}{$\begin{array}{l}\text { Bone resorption marker: S-CTx (cross-linked C-terminal telopeptide): } \\
\text { between-group ratio } 1.15 \pm 0.17, P=0.320 \text { serum alkaline phosphatase, } \\
\text { calcium and phosphate - unaffected }\end{array}$} \\
\hline & PLB & \\
\hline \multirow[t]{3}{*}{ Monami et al., 2011 [52] } & DPP-4 & \multirow{2}{*}{$\begin{array}{l}\uparrow \text { risk of bone fractures Mantel Haenszel odds ratio [MH-OR] 0.60, } 95 \% \\
\text { Cl } 0.37-0.99, P=0.045\end{array}$} \\
\hline & $\begin{array}{l}\text { PLB, other } \\
\text { treatments }\end{array}$ & \\
\hline & & Risk of cardiovascular complications \\
\hline \multirow[t]{3}{*}{ Dormandy et al., 2005 [55] } & $\mathrm{PIO}$ & $\begin{array}{l}\downarrow \text { all-cause mortality, non-fatal myocardial infarction, and stroke (main } \\
\text { secondary endpoint) }\end{array}$ \\
\hline & & $\uparrow \mathrm{HF}(11 \%$ vs. $8 \%, p<0.0001)$ \\
\hline & PLB & \\
\hline \multirow[t]{3}{*}{ Wilcox et al., 2007 [56] } & $\mathrm{PIO}$ & $\downarrow$ fatal or nonfatal stroke $(\mathrm{HR}=0.53,95 \% \mathrm{Cls}=0.34-0.85 ; P=0.0085)$ \\
\hline & & $\begin{array}{l}\downarrow \text { cardiovascular death, nonfatal myocardial infarction, or nonfatal stroke } \\
(\mathrm{HR}=0.72,95 \% \mathrm{Cls}=0.53-1.00 ; P=0.0467)\end{array}$ \\
\hline & PLB & \\
\hline Nissen et al., 2007 [57] & ROSI & $\uparrow$ myocardial infarction $(\mathrm{OR}=1.43,95 \% \mathrm{Cl}, 1.03-1.98 ; P=0.03)$ \\
\hline
\end{tabular}


Table 3 Comparative table of clinical trials and studies, investigating the safety of treatment with gliptins and glitazones (Continued)

\begin{tabular}{|c|c|c|}
\hline & & $\uparrow$ death from cardiovascular causes $(\mathrm{OR}=1.64,95 \% \mathrm{Cl}, 0.98-2.74 ; P=0.06)$ \\
\hline & Control group & \\
\hline \multirow[t]{3}{*}{ Lincoff et al., 2007 [59] } & $\mathrm{PIO}$ & $\downarrow$ death, myocardial infarction, or stroke $(\mathrm{OR}=1.43,95 \% \mathrm{Cl}, 1.03-1.98 ; P=0.03)$ \\
\hline & & $\uparrow \mathrm{HF}(\mathrm{HR}, 1.41 ; 95 \% \mathrm{Cl}, 1.14-1.76 ; P=0.002)$ \\
\hline & Control group & \\
\hline \multirow[t]{3}{*}{ Gallagher et al., 2011 [63] } & $\mathrm{PIO}$ & \\
\hline & ROSI & $\uparrow$ death (RR 1.20; $95 \%$ Cl 1.08-1.34) \\
\hline & & $\uparrow \mathrm{HF}(\mathrm{RR} 1.73 ; 95 \% \mathrm{Cl} 1.19-2.51)$ \\
\hline \multirow[t]{3}{*}{ Breunig et al., 2014 [62] } & $\mathrm{PIO}$ & \\
\hline & ROSI & $\uparrow \mathrm{HF}(\mathrm{HR}=1,79,95 \% \mathrm{Cl}=1.16-2.76, P=0.009)$ \\
\hline & MET & \\
\hline \multirow[t]{4}{*}{ Seong et al., 2015 [61] } & $\mathrm{PIO}+\mathrm{MET}$ & $\downarrow$ risk of CVD 0.89 (95 \% Cl, 0.81-0.99) \\
\hline & & $\downarrow$ risk of IS 0.81 (95 \% Cl, 0.67-0.99) \\
\hline & & 个risk of HF 4.81 (95 \% Cl, 3.53-6.56) \\
\hline & DPP-4i + MET & \\
\hline Scirica et al., 2013 [65] & SAXA & $\uparrow \mathrm{HF}(\mathrm{HR} 1.27 ; 95 \% \mathrm{Cl}, 1.07-1.51 ; P=0.007)$ \\
\hline Scirica et al., 2014 [66] & PLB & \\
\hline \multirow[t]{2}{*}{ Monami et al., 2014 [67] } & DPP-4 inhibitors & $\uparrow \mathrm{HF}(\mathrm{MH}-\mathrm{OR}: 1.19[1.03 ; 1.37] ; p=0.015)$ \\
\hline & Control group & \\
\hline \multirow[t]{2}{*}{ Clifton P, 2014 [68] } & DPP-4 inhibitors & $\uparrow \mathrm{HF}$ \\
\hline & Control group & \\
\hline \multirow[t]{2}{*}{ Wang et al., 2014 [69] } & SIT & $\uparrow \mathrm{HF}(\mathrm{HR}: 1.09,95 \% \mathrm{Cl}: 1.06-1.11, P<0.001)$. \\
\hline & Control group & \\
\hline \multirow[t]{4}{*}{ Chen et al., 2014 [70] } & SIT & $\uparrow$ recurrent myocardial infarction $(\mathrm{HR}, 1.73 ; 95 \% \mathrm{Cl}, 1.15-2.58 ; P=0.008)$ \\
\hline & & $\uparrow$ percutaneous coronary revascularization ( $\mathrm{HR}, 1.43 ; 95 \% \mathrm{Cl}, 1.04-1.95 ; P=0.026)$ \\
\hline & Control group & \\
\hline & & Effects on liver \\
\hline \multirow[t]{7}{*}{ Belfort et al., 2006 [72] } & $\mathrm{PIO}$ & $\downarrow$ alanine transaminase (by $58 \%$ vs. $34 \%, P<0.001$ ) \\
\hline & & 个hepatic insulin sensitivity (by $48 \%$ vs. $14 \%, P=0.008$ ) \\
\hline & & $\downarrow$ liver fat (by $54 \%$ vs. $0 \%, P<0.001$ ) \\
\hline & & $\downarrow$ liver inflammation $(P=0.008)$ \\
\hline & & $\downarrow$ ballooning necrosis $(P=0.02)$ \\
\hline & & Fibrosis not improved $(P=0.08)$ \\
\hline & PLB & \\
\hline \multirow[t]{7}{*}{ Aithal et al., 2008 [73] } & $\mathrm{PIO}$ & $\downarrow$ hepatocellular injury $(P=0.005)$ \\
\hline & & $\downarrow$ Mallory-Denk bodies $(P=0.004)$ \\
\hline & & $\downarrow$ alanine aminotransferase level $(-10.9 \mathrm{vs}-36.2 \mathrm{u} / \mathrm{L} ; P=0.009)$ \\
\hline & & $\downarrow$ gamma-glutamyltransferase level (-9.4 vs $-41.2 \mathrm{u} / \mathrm{L} ; P=0.002)$ \\
\hline & & $\downarrow$ ferritin $(-11.3$ vs $-90.5 \mu \mathrm{g} / \mathrm{L} ; P=0.01)$ \\
\hline & & Fibrosis improved $(P=0.05)$ \\
\hline & PLB & \\
\hline \multirow[t]{4}{*}{ Sanyal et al., 2010 [74] } & $\mathrm{PIO}$ & $\downarrow$ serum alanine and aspartate aminotransferase levels $(P<0.001)$ \\
\hline & & $\downarrow$ insulin resistance $(P=0.03)$ \\
\hline & & $\downarrow$ liver inflammation $(P=0.004)$ \\
\hline & & $\downarrow$ ballooning necrosis $(P=0.08)$ \\
\hline
\end{tabular}


Table 3 Comparative table of clinical trials and studies, investigating the safety of treatment with gliptins and glitazones (Continued)

\begin{tabular}{|c|c|c|}
\hline & & Fibrosis not improved $(P=0.12)$ \\
\hline & PLB & \\
\hline \multirow[t]{6}{*}{ Ohki et al., 2012 [77] } & SIT & $\downarrow$ aspartate aminotransferase $(P=0.47)$ \\
\hline & & $\downarrow$ alanine aminotransaminase $(P=0.03)$ \\
\hline & & $\downarrow$ gamma-glutamyltransferase $(P=0.01)$ \\
\hline & $\mathrm{PIO}$ & $\downarrow$ aspartate aminotransferase $(P<0.01)$ \\
\hline & & $\downarrow$ alanine aminotransaminase $(P<0.01)$ \\
\hline & & $\downarrow$ gamma-glutamyltransferase $(P<0.01)$ \\
\hline Iwasaki et al., 2011 [75] & SIT & $\downarrow$ alanine transaminase, aspartate aminotransferase, gamma-glutamyltransferase \\
\hline \multirow[t]{4}{*}{ Itou et al., 2012 [76] } & SIT - case report & $\downarrow$ alanine transaminase, aspartate aminotransferase \\
\hline & & $\downarrow$ insulin resistance \\
\hline & & $\downarrow$ liver fat \\
\hline & & Risk of development of oncological disease \\
\hline Azoulay et al., 2013 [2] & $\mathrm{PIO}$ & $\uparrow$ bladder cancer (RR 1.83, 95 \% Cl 1.10-3.05) \\
\hline \multirow[t]{2}{*}{ Wei et al., 2013 [87] } & $\mathrm{PIO}$ & $\downarrow$ bladder cancer $(\mathrm{HR}, 1.16,95 \% \mathrm{Cl} 0.83,1.62)$ \\
\hline & Active control & \\
\hline \multirow[t]{2}{*}{ Govindarajan et al., 2007 [34] } & $\mathrm{PIO}$ & \lung cancer (RR, 0.67; $95 \% \mathrm{Cl}, 0.51-0.87)$ \\
\hline & Active control & \\
\hline \multirow[t]{2}{*}{ Mazzone et al., 2012 [56] } & TZDs & $\downarrow$ lung cancer (OR 0.86, $95 \% \mathrm{Cl} 0.4-1.85, p=0.14)$ \\
\hline & MET & $\downarrow$ lung cancer (OR 0.48, $95 \% \mathrm{Cl} 0.28-0.81, p=0.006)$ \\
\hline Nelson et al., 2014 [31] & SIT - case report & $\uparrow$ pancreatitis \\
\hline Girgis and Champion, 2011 [81] & VIL - case report & $\uparrow$ acute pancreatitis \\
\hline Singh et al., 2013 [27] & EQW/SIT & acute pancreatitis (OR 2.01, $95 \% \mathrm{Cl}[1.37-3.18], P=0.01)$ \\
\hline \multirow[t]{2}{*}{ Engel et al., 2013 [45] } & SIT Comparator agent & Rates of malignancy $(-0.05(95 \% \mathrm{Cl}-0.41,0.30)$ \\
\hline & & $\begin{array}{l}\text { Rate of category of pancreatic cancer (adenocarcinoma of pancreas, pancreatic } \\
\text { carcinoma, pancreatic carcinoma metastatic) ( } 0.05 \text { and } 0.06 \text { events per } 100 \\
\text { patient-years in the sitagliptin and nonexposed groups, respectively) }\end{array}$ \\
\hline
\end{tabular}

ROS/ rosiglitazone, SAXA saxagliptin, ALO alogliptin, BMD bone mineral density, CVD cardiovascular disease, IS ischemic stroke

complications, non-fatal myocardial infarction or non-fatal stroke $(13.0 \%$ in the pioglitazone group against $17.7 \%$ in the placebo group) compared with placebo [56].

Whilst a meta-analysis has raised concerns regarding the possibility of cardiovascular complications associated with rosiglitazone $[57,58]$, another meta-analysis of pioglitazone trials showed that among the diverse population of patients with T2DM, treatment with pioglitazone was associated with a significant decrease in risk of myocardial infarction, stroke or death $[59,60]$. The results of a population-based cohort study showed that pioglitazone + metformin was associated with decreased risks of total cardiovascular disease and ischemic stroke compared with DPP-4 inhibitor + metformin. However, the risk of HF was higher in patients receiving pioglitazone + metformin [61]. Compared with metformin the risk of developing HF in Medicaid (US government insurance program) patients was higher in patients started on rosiglitazone, but not pioglitazone [62]. The study, which supported the suspension of rosiglitazone by European regulatory authorities in
September 2010, determined that current rosiglitazone users had an increased risk of death (adjusted RR 1.20; 95 $\%$ CI 1.08-1.34) and hospitalization for HF (adjusted RR 1.73; 95 \% CI 1.19-2.51) compared to current pioglitazone users [63]. The difference between rosiglitazone and pioglitazone in regard to cardiovascular complications suggests that these effects are rather associated with the TZD type, but are not a drug class effect. It was found that pioglitazone is associated with greater PPAR- $\gamma$ activation than rosiglitazone [64]. A retrospective review showed that treatment with pioglitazone was associated with greater beneficial effects on blood lipid levels (triglycerides, total cholesterol, and LDL-C) than rosiglitazone [34]. Therefore, differential therapeutic modulation of lipid levels might confer a different level of protection from cardiovascular disease in patients with T2DM.

T2DM and HF often coexist, and together, these conditions are associated with increased morbidity and mortality compared with each of them individually. The cardiovascular safety and efficacy of pioglitazone is 
proven, while this was not done with inhibitors of DPP4. Recently (2013), cardiovascular safety and efficacy of saxagliptin was estimated in 16492 patients with T2DM and concomitant cardiovascular risk factors in the study - Saxagliptin Assessment of Vascular Outcomes Recorded in Patients With Diabetes Mellitus (SAVOR) - Thrombolysis in Myocardial infarction (TIMI) 53. Scirica et al. analyzed in detail the risk of occurrence of HF in this study. It was found that more patients in the saxagliptin group are hospitalized due to HF (3.5 \% vs. $2.8 \%$; HR, 1.27; $95 \%$ CI, 1.07 to 1.51 ; $P=0.007)$ and this DPP-4 inhibitor did not provide any cardioprotective benefit $[65,66]$. In a meta-analysis that included 84 studies it was established that the overall risk of HF was higher in patients treated with DPP-4 inhibitors compared with placebo/active control without any clear evidence of differences among drugs of the class [67]. Data from another meta-analysis revealed that in the randomized, controlled trials (including sitagliptin, saxagliptin and alogliptin) the risk of HF in patients using DPP-4 inhibitors was 24\% [68].

The available evidence suggests that the DPP-4 inhibitors are associated with increased risk of HF [67-69] as well as they have unproven safety with respect to the cardiovascular system. Patients with T2DM, chronic kidney disease and acute myocardial infarction were included in a cohort study which demonstrated that using sitagliptin increased the risk of recurrent myocardial infarction and percutaneous coronary revascularization [70].

In 2008 the Food and Drug Administration (FDA) in the United States required that the cardiovascular safety for all glucose lowering drugs was proven, and this began to be applied to new antidiabetic drugs: DPP-4 inhibitors. In 2013-2014 many studies with DPP-4 inhibitors were conducted, which have definitely shown a higher risk of developing HF and the cardiovascular safety of these inhibitors has to be demonstrated. On the other hand, the benefits and safety of pioglitazone on the cardiovascular system have been well established. Recently, post- marketing trials of DPP-4 inhibitors have shown that these drugs neither reduce nor increase the risk of major cardiovascular events compared with placebo $[65,71]$. The safety of gliptins regarding the cardiovascular system has not been established in the long term.

Another advantage of pioglitazone, which characterizes its safe and efficient profile is its effect on liver histology, and hence its use for treatment of nonalcoholic fatty liver disease. Several studies have shown that the use of pioglitazone leads to reduced levels of liver enzymes and inflammatory markers of necrosis and improvements of fibrosis, steatosis and insulin sensitivity [72-74]. Several clinical studies with sitagliptin in subjects with T2DM and nonalcoholic steatohepatitis have shown decreases in alanine aminotransferase levels and improved liver histology [75-77]. Clinical data for the DPP-4 inhibitors is very scarce and the information is derived from non-randomized studies conducted in small groups of patients; this is why it is difficult to make final conclusions [78, 79].

Definitive data in humans, associating the TZDs with cancer development is not available. Azoulay et al., reported an increased risk of bladder cancer in the group of patients using pioglitazone (HR 1.83; 95 \% CI 1.10-3.05) [80], while Wei et al., analyzed the risk in 23,548 patients exposed to pioglitazone and 184,166 exposed to other antidiabetic treatments and reported that pioglitazone may not be significantly associated with an increased risk of bladder cancer (1.16; 95 \% CI 0.83-1.62) [81, 82]. The largest study examining the side effects of pioglitazone PROactive detected more cases of bladder cancer in the pioglitazone group, although the difference was not statistically significant. But in the same trial statistically significant reduction of cases with breast cancer in the pioglitazone group was observed. Other studies have demonstrated the protective effect of TZDs against the development of lung cancer in patients with diabetes [83, 84]. The Agency's Committee for Medicinal Products for Human Use (CHMP) concluded that, although there is a small risk

Table 4 Cost of monthly therapy

\begin{tabular}{lllll}
\hline Product & $\begin{array}{l}\text { DDD, } \\
\mathrm{mg}\end{array}$ & $\begin{array}{l}\text { Cost of DDD, } \\
\text { BGN (EUR) }\end{array}$ & $\begin{array}{l}\text { Cost of monthly therapy, } \\
\text { BGN (EUR) }\end{array}$ & $\begin{array}{l}\text { Relative difference in the } \\
\text { cost versus PIO or PIO + MET, \% }\end{array}$ \\
\hline PIO & 30 & $1.56156(0.79841)$ & $46.84(23.95)$ & - \\
SIT & 100 & $2.64929(1.35456)$ & $79.48(40.64)$ & +70 \\
VIL & 100 & $2.73429(1.39802)$ & $82.03(41.94)$ & +75 \\
PIO + MET 15/850 mg & $30 / 2000$ & $1.68522(0.86164)$ & $50.56(25.85)$ & - \\
PIO + MET 15/1000 mg & $30 / 2000$ & $1.68522(0.86164)$ & $50.56(25.85)$ & +89 \\
SIT + MET 50/850 mg & $100 / 2000$ & $3.18204(1.62695)$ & $95.46(48.81)$ & +90 \\
SIT + MET 50/1000 mg & $100 / 2000$ & $3.20408(1.63822)$ & $96.12(49.15)$ & +93 \\
VIL + MET 50/850 mg & $100 / 2000$ & $3.24533(1.65931)$ & $97.36(49.78)$ & +83 \\
VIL + MET 50/1000 mg & $100 / 2000$ & $3.08333(1.57407)$ & $92.50(47.29)$ & \\
\hline
\end{tabular}


Table 5 Effectiveness of annual costs during treatment with pioglitazone (monotherapy and combination therapy) in Bulgaria

\begin{tabular}{|c|c|c|c|c|c|c|}
\hline Treatment & $\begin{array}{l}\text { Number of packs } \\
\text { sold in } 2014\end{array}$ & Expenses, BGN (EUR) & $\begin{array}{l}\text { Number of patients } \\
\text { taking DDD }\end{array}$ & $\begin{array}{l}\text { Cost of therapy with PIO } \\
\text { or PIO + MET, BGN (EUR) }\end{array}$ & Difference, BGN (EUR) & $\begin{array}{l}\text { Amount reimbursed by } \\
\text { the NHIF, BGN (EUR) }\end{array}$ \\
\hline SIT & 25,072 & $1,859,840.96(950,921.58)$ & 25,072 & $1,177,623.20(602,109.18)$ & $682,217.76(348,812.40)$ & $682,217.76(348,812.40)$ \\
\hline VIL & 6,088 & 233,048.64 (119,155.88) & 3,044 & $142,611.40(72,916.05)$ & $90,437.24(46,239.83)$ & $90,437.24(46,239.83)$ \\
\hline SIT + MET 50/850 mg & 141,986 & $6,325,476.30(3,234,164.68)$ & 70,993 & $3,588,696.15(1,834,871.21)$ & $2,736,780.15(1,399,293.47)$ & $1,368,390.07(699,646.73)$ \\
\hline SIT + MET 50/1000 mg & 257,550 & $11,553,693.00(5,907,309.43)$ & 128,775 & $6,508,288.50(3,327,634.81)$ & $5,045,404.50(2,579,674.36)$ & $2,522,702.25(1,289,837.18)$ \\
\hline VIL + MET 50/850 mg & 53,980 & $5,255,492.80(2,687,090.80)$ & 26,990 & $1,364,344.50(697,578.27)$ & $3,891,148.30(1,989,512.53)$ & $1,945,574.15(994,756.27)$ \\
\hline VIL + MET 50/1000 mg & 128,665 & $11,901,512.50(6,085,146.72)$ & $64,332.5$ & $3,251,364.55(1,662,396.30)$ & $8,650,147.95(4,422,750.42)$ & $4,325,074.98(2,211,375.72)$ \\
\hline Total: & 613,341 & $37,129,064.20(18,983,789.08)$ & $319,206.5$ & $16,032,928.30(8,197,183.96)$ & $21,096,135.90(10,786,283.01)$ & $10,934,395.45(5,590,649.35)$ \\
\hline
\end{tabular}


of bladder cancer with pioglitazone, its benefits continue to outweigh its risks in a limited population of type 2 diabetes patients (www.ema.europa.eu - Accessed on 21/7/201). On the other hand, data from studies, warnings of the European Medicines Agency (EMA) and the FDA have shown that there is increased risk of developing acute pancreatitis and pancreatic cancer in therapy with incretin-based agents: exenatide, liraglutide, sitagliptin, saxagliptin, vildagliptin, alogliptin and linagliptin. A lot of conflicting data [85-89] concerning the serious side effects of incretin-based therapies is currently available and published each month. Nevertheless, the widespread use of these drugs, the evaluation of short- and long-term risks should be considered as a priority [90].

Based on these facts, the balance between benefits and risks supports the use of pioglitazone to reduce the morbidity and mortality associated with T2DM.

\section{Costs comparison}

In order to determine the benefits in terms of costs, the defined daily dose, the monthly cost of the treatment course and the level of reimbursement by the National Health Insurance Fund (NHIF) should be taken into account. The defined daily dose (DDD) for pioglitazone is $30 \mathrm{mg}$, and for sitagliptin and vildagliptin - $100 \mathrm{mg}$. According to the updated PDL the reimbursement rate for pioglitazone is $25 \%$. In comparison, sitagliptin and vildagliptin are reimbursed at $100 \%$ by NHIF, despite their much higher wholesale price. Table 4 provides the reference prices of mono and combination therapies with the three antihyperglycemic drugs. All prices are given in BGN and EUR with current exchange rates of 1.95583 BGN for 1 EUR according to Bulgarian National Bank.

Given that the effectiveness of pioglitazone is comparable or even better than that of gliptins and it has shown better safety than them, then the exchange of mono- and combination therapy with gliptins with monotherapy and combination therapy with pioglitazone will allow savings of public funds to be realized by NHIF.

Data on the amount of sold packs of sitagliptin, vildagliptin and their combination with metformin has been taken from IMS Health database. It was estimated that if sitagliptin or vildagliptin monotherapy was exchanged with pioglitazone monotherapy and it was reimbursed by $100 \%$ 682,217.76 BGN (348,812.40 EUR) and 90,437.24 BGN (46,239.83 EUR) will be saved, respectively (Table 5).

Therefore, if therapies with sitagliptin + metformin and vildagliptin + metformin are replaced with pioglitazone + metformin and reimbursed at $50 \%$, the NHIF would realize savings for BGN 10,161,740.45 (5,195,615.39 EUR).

Our results are confirmed by Klarenbach et al., who used the United Kingdom Prospective Diabetes Study Outcomes Model to predict diabetes-related complications, quality- adjusted life-years (QALY) and costs of alternative secondline therapies available in Canada for adults with T2DM inadequately controlled by metformin. DPP-4 inhibitors, basal insulin and biphasic insulin are more costly and lead to fewer QALYs than TZDs, they are dominated by the TZDs (which are less expensive and more effective) [91].

An economic modeling analysis carried out in the USA suggested that pioglitazone may deliver superior economic value when compared to sitagliptin due to improved $\mathrm{HbA}_{1 \mathrm{c}}$ and cardiovascular outcomes at reasonable incremental cost [92].

\section{Conclusion}

Pioglitazone has a glycemic profile which is superior or similar to that of newer antidiabetic drugs (DPP-4 inhibitors). It does not increase the risk of cardiovascular complications and has a manageable safety profile. At present the commonly used therapies with newer drugs (sitagliptin and vildagliptin) seem to be both less effective and less safe. Furthermore, none affect insulin sensitivity as beneficially as pioglitazone. In addition to its favorable effect on glycemic parameters pioglitazone proves to be cost-effective when compared to sitagliptin and vildagliptin. Nevertheless, gliptins have a growing market share, despite the lack of data on long-term safety and their higher price. If the drug and reimbursement policy in Bulgaria follows the principles for reimbursement of cost-effective treatments and gives preference to pioglitazone, it could save up to BGN 10,934,395.45 (5,590,649.35 EUR).

\section{Abbreviations}

T2DM: Type 2 diabetes mellitus; TZD: Thiazolidinediones; PPARs: Peroxisome proliferator-activated receptors; DPP-4: Dipeptidyl peptidase-4; NICE: National Institute for Health and Care Excellence; $\mathrm{HbA}_{1 c}$ : Glycated hemoglobin; PDL: Positive drug list; FPG: Fasting plasma glucose; HDL: High-density lipoprotein; LDL: Low-density lipoprotein; HF: Heart failure; FDA: Food and drug administration; EMA: European medicines agency; NHIF: National health insurance fund; DDD: Defined daily dose; QALY: Quality-adjusted life-years.

\section{Competing interests}

The authors declare that they have no competing interests.

\section{Authors' contributions}

EF, TV: Wrote sections on efficacy of pioglitazone. KU, TV: Wrote sections on safety of pioglitazone. EF, KU, TV: Wrote sections on costs comparison. All authors read and approved the final manuscript.

\section{Acknowledgements}

The authors wish to thank Rossitsa Tuneva for providing support as a language editor.

\section{Author details}

${ }^{1}$ Science Department, Tchaikapharma High Quality Medicines, Inc, 1 G.M. Dimitrov Blvd, 1172 Sofia, Bulgaria. ${ }^{2}$ Department of Medical ethics, management of health care and information technology, Medical University, Pleven, Bulgaria.

Received: 6 April 2015 Accepted: 8 July 2015

Published online: 16 July 2015 


\section{References}

1. Jindal A, Kaur R, Jindal M. Comparative study: Efficacy and tolerability of vildagliptin vs. pioglitazone as an add-on therapy to metformin in poorly controlled type 2 diabetes mellitus patients in Punjab. IAIM. 2015;2(1):83-94.

2. Lehmann JM, Moore LB, Smith-Oliver TA, Wilkison WO, Willson TM, Kliewer SA. An antidiabetic thiazolidinedione is a high affinity ligand for peroxisome proliferator-activated receptor gamma (PPAR gamma). J Biol Chem. 1995:270:12953-6.

3. Malik S, Upadhyaya PK, Miglani S. Thiazolidinediones: A Plethro of Biological Load. Int J PharmTech Res. 2011;3(1):62-75.

4. Krishnaswami A, Ravi-Kumar S, Lewis JM. Thiazolidinediones: A 2010 Perpective. Permanente J. 2010;14(3):64-72.

5. NICE guidelines for the management of type 2 diabetes, last modified Dec. 2014

6. Inzucchi SE, Bergenstal RM, Buse JB, Diamant M, Ferrannini E, Nauck M, et al. Management of hyperglycemia in type 2 diabetes, 2015: a patient-centered approach: update to a position statement of the American Diabetes Association and the European Association for the Study of Diabetes. Diabetes Care. 2015;38(1):140-9.

7. Banerjee S. Pioglitazone safe. So Safe JAPI. 2012;60:62-6.

8. Lü ZH, Pan CY, Gao Y, Guo LX, Ning G, Liu ZM, et al. A randomized, double blind, placebo-controlled, parallel and multicenter study to evaluate the safety and efficacy of pioglitazone with sulphonylurea in type 2 diabetic patients. Zhonghua Nei Ke Za Zhi. 2011;50(10):826-30.

9. Scherbaum WA, Göke B, German Pioglitazone Study Group. Metabolic efficacy and safety of once-daily pioglitazone monotherapy in patients with type 2 diabetes: a double-blind, placebo-controlled study. Horm Metab Res. 2002;34(10):589-95.

10. Yang W, Guan Y, Shentu Y, Li Z, Johnson-Levonas AO, Engel SS, et al. The addition of sitagliptin to ongoing metformin therapy significantly improves glycemic control in Chinese patients with type 2 diabetes. J Diabetes. 2012:4(3):227-37.

11. Barzilai N, Guo H, Mahoney EM, Caporossi S, Golm GT, Langdon RB, et al. Efficacy and tolerability of sitagliptin monotherapy in elderly patients with type 2 diabetes: a randomized, double-blind, placebo-controlled trial. Curr Med Res Opin. 2011;27(5):1049-58.

12. Yang $W$, Xing $X, L \vee X, L i$ Y, Ma J, Yuan G, et al. Vildagliptin added to sulfonylurea improves glycemic control without hypoglycemia and weight gain in Chinese patients with type 2 diabetes mellitus 2. J Diabetes. 2015;7(2):174-81.

13. Craddy P, Palin HJ, Johnson Kl. Comparative effectiveness of dipeptidylpeptidase-4 inhibitors in type 2 diabetes: a systematic review and mixed treatment comparison. Diabetes Ther. 2014;5(1):1-41.

14. Choe EY, Cho Y, Choi Y, Yun Y, Wang HJ, Kwon O, et al. The effect of DPP-4 inhibitors on metabolic parameters in patients with type 2 diabetes. Diabetes Metab J. 2014;38(3):211-9.

15. Lukashevich $\mathrm{V}$, Prato SD, Araga M, Kothny W. Efficacy and safety of vildagliptin in patients with type 2 diabetes mellitus inadequately controlled with dual combination of metformin and sulphonylurea. Diabetes Obes Metab. 2014;16(5):403-9.

16. Freed MI, Ratner R, Marcovina SM, Rosiglitazone Study 108 investigators. Effects of rosiglitazone alone and in combination with atorvastatin on the metabolic abnormalities in type 2 diabetes mellitus. Am J Cardiol. 2002;90:947-52.

17. Baetta R, Corsini A. Pharmacology of dipeptidyl peptidase-4 inhibitors: similarities and differences. Drugs. 2011;71:1441-67.

18. Russell-Jones D, Cuddihy RM, Hanefeld M, Kumar A, González JG, Chan M, et al. Efficacy and safety of exenatide once weekly versus metformin, pioglitazone, and sitagliptin used as monotherapy in drug-naive patients with type 2 diabetes (DURATION-4): a 26-week double-blind study. Diabetes Care. 2012;35(2):252-8.

19. Rosenstock J, Kim SW, Baron MA, Camisasca RP, Cressier F, Couturier A, et al. Efficacy and tolerability of initial combination therapy with vildagliptin and pioglitazone compared with component monotherapy in patients with type 2 diabetes. Diabetes Obes Metab. 2007;9(2):175-85.

20. Pérez-Monteverde A, Seck T, Xu L, Lee MA, Sisk CM, Williams-Herman DE, et al. Efficacy and safety of sitagliptin and the fixed-dose combination of sitagliptin and metformin vs. pioglitazone in drug-naïve patients with type 2 diabetes. Int J Clin Pract. 2011;65(9):930-8.

21. Karagiannis T, Paschos P, Paletas K, Matthews DR, Tsapas A. Dipeptidyl peptidase-4 inhibitors for treatment of type 2 diabetes mellitus in the clinical setting: systematic review and meta-analysis. BMJ. 2012;344:e1369.
22. Stolar M. Safety and efficacy of pioglitazone/metformin combination therapy in treatment of type 2 diabetes. Clin Med. 2009;1:289-303.

23. Mikhail N. Combination therapy with DPP-4 inhibitors and pioglitazone in type 2 diabetes: theoretical consideration and therapeutic potential. Vasc Health Risk Manag. 2008;4(6):1221-7.

24. van Genugten RE, van Raalte DH, Diamant M. Dipeptidyl peptidase-4 inhibitors and preservation of pancreatic islet-cell function: a critical appraisal of the evidence. Diabetes Obes Metab. 2012;14(2):101-11.

25. Chawla S, Kaushik N, Singh NP, Ghosh RK, Saxena A. Effect of addition of either sitagliptin or pioglitazone in patients with uncontrolled type 2 diabetes mellitus on metformin: a randomized controlled trial. J Pharmacol Pharmacother. 2013;4(1):27-32.

26. Liu SC, Chien KL, Wang CH, Chen WC, Leung CH. Efficacy and safety of adding pioglitazone or sitagliptin to patients with type 2 diabetes insufficiently controlled with metformin and a sulfonylurea. Endocr Pract. 2013;19(6):980-8.

27. Bergenstal RM, Wysham C, Macconell L, Malloy J, Walsh B, Yan P, et al. Efficacy and safety of exenatide once weekly versus sitagliptin or pioglitazone as an adjunct to metformin for treatment of type 2 diabetes (DURATION-2): a randomised trial. Lancet. 2010;376(9739):431-9.

28. Lee YK, Song SO, Kim KJ, Cho Y, Choi Y, Yun Y, et al. Glycemic effectiveness of metformin-based dual-combination therapies with sulphonylurea, pioglitazone, or DPP-4-inhibitor in drug-naïve Korean type 2 diabetic patients. Diabetes Metab J. 2013;37(6):465-74.

29. Blonde L, Dagogo-Jack S, Banerji MA, Pratley RE, Marcellari A, Braceras R, et al. Comparison of vildagliptin and thiazolidinedione as add-on therapy in patients inadequately controlled with metformin: results of the GALIANT trial-a primary care, type 2 diabetes study. Diabetes Obes Metab. 2009;11(10):978-86.

30. Bolli G, Dotta F, Rochotte E, Cohen SE. Efficacy and tolerability of vildagliptin vs. pioglitazone when added to metformin: a 24-week, randomized, doubleblind study. Diabetes Obes Metab. 2008;10(1):82-90.

31. Bolli G, Dotta F, Colin L, Minic B, Goodman M. Comparison of vildagliptin and pioglitazone in patients with type 2 diabetes inadequately controlled with metformin. Diabetes Obes Metab. 2009;11(6):589-95.

32. Kaur M, Rai J, Bal BS, Kaur J. The impact of three combinations vildagliptin/ metformin, vildagliptin/pioglitazone, and metformin/pioglitazone on glycemic control and atherogenic dyslipidemia in patients with type 2 diabetes mellitus. Int J Basic Clin Pharmacol. 2014;3(5):902-7.

33. Kaur K, Kaur R, Mittal N, Arora S, Kaushal S. Comparison of efficacy of add-on therapy of vildagliptin versus pioglitazone among type 2 diabetes mellitus patients inadequately controlled on dual therapy of metformin plus sulfonylurea. Asian J Med Sci. 2014;5(3):77-81.

34. van Wijk JP, de Koning EJ, Martens EP, Rabelink TJ. Thiazolidinediones and blood lipids in type 2 diabetes. Arterioscler ThrombVasc Biol. 2003;23:1744-9.

35. Goldberg RB, Kendall DM, Deeq MA, Buse JB, Zagar AJ, Pinaire JA, et al. A comparison of lipid glycemic effects of pioglitazone and rosiglitazone in patient with type 2 diabetes and dyslipidemia. Diabetes Care. 2005:28(7):1547-54.

36. Schernthaner G. Pleiotropic effects of thiazolidinediones on traditional and nontraditional atherosclerotic risk factors. Int J Clin Pract. 2009;63:912-29.

37. Nissen SE, Nicholls SJ, Wolski K, PERISCOPE Investigators. Comparison of pioglitazone vs glimepiride on progression of coronary atherosclerosis in patients with type 2 diabetes: the PERISCOPE randomized controlled trial. JAMA. 2008;299:1561-73.

38. Mazzone T, Meyer PM, Feinstein SB, Davidson MH, Kondos GT, D'Agostino $\mathrm{RB}$, et al. Effect of pioglitazone compared with glimepiride on carotid intima-media thickness in type 2 diabetes. JAMA. 2006;296:2572-81.

39. McGuire DK, Inzucchi SE. New drugs for the treatment of diabetes mellitus: part I: Thiazolidinediones and their evolving cardiovascular implications. Circulation. 2008;117(3):440-9

40. Stolar MW, Hoogwerf BJ, Gorshow SM, Boyle PJ, Wales DO. Managing type 2 diabetes: going beyond glycemic control. J Manag Care Pharm. 2008;14(suppl S-b):S2-19.

41. DeFronzo RA, Tripathy D, Schwenke DC, Banerji M, Bray GA, Buchanan TA, et al. Pioglitazone for diabetes prevention in impaired glucose tolerance. N Engl J Med. 2011;364:1104-15.

42. Mearns ES, Sobieraj DM, White CM, Saulsberry WJ, Kohn CG, Doleh Y, et al. Comparative efficacy and safety of antidiabetic drug regimens added to metformin monotherapy in patients with type 2 diabetes: a network meta-analysis. PLoS One. 2015;10(4), e0125879. 
43. Dormandy J, Bhattacharya M, van Troostenburg de Bruyn AR. Safety and tolerability of pioglitazone in high-risk patients with type 2 diabetes: an overview of data from PROactive. Drug Saf. 2009;32:187-202.

44. Canada H. Association between long-term treatment with Actos (pioglitazone hydrochloride; tablets for type 2 diabetes mellitus and fractures in women. 2007.

45. Meymeh $\mathrm{RH}$, Wooltorton E. Diabetes drug pioglitazone (Actos): risk of fracture. CMAJ. 2007;177:723-4.

46. Bazelier MT, Vestergaard P, Gallagher AM, van Staa TP, Cooper C, Leufkens HGM, et al. Risk of fracture with thiazolidinediones:disease or drugs? Calcif Tissue Int. 2012;90:450-7.

47. Glintborg D, Andersen M, Hagen C, Heickendorff L, Hermann AP. Association of pioglitazone treatment with decreased bone mineral density in obese premenopausal patients with polycystic ovary syndrome: a randomized, placebo-controlled trial. J Clin Endocrinol Metab. 2008;93:1696-701.

48. Meier C, Kraenzlin ME, Bodmer M, Jick SS, Jick H, Meier CR. Use of thiazolidinediones and fracture risk. Arch Intern Med. 2008;168(8):820-5.

49. Colhoun HM, Livingstone SJ, Looker HC, Morris AD, Wild SH, Lindsay RS, et al. Hospitalized hip fracture risk with rosiglitazone and pioglitazone use compared with other glucose-lowering drugs. Diabetologia. 2012;55:2929-37.

50. Bone HG, Lindsay R, McClung MR, Perez AT, Raanan MG, Spanheimer RG Effects of pioglitazone on bone in postmenopausal women with impaired fasting glucose or impaired glucose tolerance:A randomized, double-blind, placebo-controlled study. J Clin Endocrinol Metab. 2013;98:4691-701.

51. Lecka-Czernik B. Safety of anti-diabetic therapies on bone. Clin Rev Bone Miner Metab. 2013;11(1):49-58.

52. Monami M, Dicembrini I, Antenore A, Mannucci E. Dipeptidyl peptidase-4 inhibitors and bone fractures: a meta-analysis of randomized clinical trials. Diabetes Care. 2011;34(11):2474-6.

53. Bunck MC, Poelma M, Eekhoff EM, Schweizer A, Heine RJ, Nijpels G, et al. Effects of vildagliptin on postprandial markers of bone resorption and calcium homeostasis in recently diagnosed, well-controlled type 2 diabetes patients. J Diabetes. 2012;4(2):181-5.

54. Inc TPA. Actos (pioglitazone hydrochloride) Tablets [prescribing information]. 2007.

55. Dormandy JA, Charbonnel B, Eckland DJ, Erdmann E, Massi-Benedetti M, Moules IK, et al. Secondary prevention of macrovascular events in patients with type 2 diabetes in the PROactive Study (PROspective pioglitAzone Clinical Trial In macroVascular Events): a randomised controlled trial. Lancet. 2005;366:1279-89.

56. Wilcox R, Bousser MG, Betteridge DJ, Schernthaner G, Pirags V, Kupfer S, et al. Effects of pioglitazone in patients with type 2 diabetes with or without previous stroke: results from PROactive (PROspective pioglitAzone Clinical Trial In macroVascular Events 04). Stroke. 2007;38:865-73.

57. Nissen SE, Wolski K. Effect of rosiglitazone on the risk of myocardial infarction and death from cardiovascular causes. N Engl J Med. 2007;356(24):2457-71.

58. Lu CJ, Sun Y, Muo CH, Chen RC, Chen PC, Hsu CY. Risk of stroke with thiazolidinediones: a ten-year nationwide population-based cohort study. Cerebrovasc Dis. 2013;36(2):145-51.

59. Lincoff AM, Wolski K, Nicholls SJ, Nissen SE. Pioglitazone and risk of cardiovascular events in patients with type 2 diabetes mellitus: a meta-analysis of randomized trials. JAMA. 2007;298(10):1180-8.

60. Morgan S, Beynon J, Woolley J, Suvarna R, Raine J. Opinion of Diabetes UK and ABCD (Association of British Clinical Diabetologists), Re: Pioglitazone and bladder cancer. 2011

61. Seong JM, Choi NK, Shin JY, Chang Y, Kim YJ, Lee J, et al. Differential cardiovascular outcomes after dipeptidyl peptidase-4 inhibitor, sulfonylurea, and pioglitazone therapy, all in combination with metformin, for type 2 diabetes: a population-based cohort study. PLOS One. 2015;10(5), e0124287.

62. Breunig IM, Shaya FT, McPherson ML, Snitker S. Development of heart failure in medicaid patients with type 2 diabetes treated with pioglitazone, rosiglitazone, or Metformin. J Manag Care Specialty Pharmacy. 2014;20(9):895-903.

63. Gallagher AM, Smeeth L, Seabroke S, Leufkens HGM, van Staa TP. Risk of death and cardiovascular outcomes with thiazolidinediones: a study with the general practice research database and secondary care data. PLoS One. 2011;6(12):1-9.

64. Wurch T, Junquero D, Delhon A, Pauwels J. Pharmacological analysis of wild-type $a, y$ and $\delta$ subtypes of the human peroxisome proliferatoractivated receptor. Naunyn Schmiedebergs Arch Pharmacol. 2002;365:133-40

65. Scirica BM, Bratt DL, Braunwald E, Steg PG, Davidson J, Hirshberg B, et al. Saxaxgliptin and cardiovascular outcomes in patients with type 2 diabetes mellitus. N Engl J Med. 2013;369(14):1317-26.

66. Scirica BM, Braunwald E, Raz I, Cavender MA, Morrow DA, Jarolim P, et al Heart Failure, saxagliptin, and diabetes mellitus: observations from the SAVOR-TIMI 53 randomized trial. Circulation. 2014;130:1579-88.

67. Monami M, Dicembrini I, Mannucci E. Dipeptidyl peptidase-4 inhibitors and heart failure: a meta-analysis of randomized clinical trials. Nutr Metab Cardiovasc Dis. 2014;24(7):689-97.

68. Clifton P. Do dipeptidyl peptidase IV (DPP-IV) inhibitors cause heart failure? Clin Ther. 2014;36(12):2072-9.

69. Wang KL, Liu CJ, Chao TF, Huang CM, Wu CH, Chen SJ, et al. Sitagliptin and the risk of hospitalization for heart failure: a population-based study. Int J Cardiol. 2014;177(1):86-90.

70. Chen DY, Wang SH, Mao CT, Tsai ML, Lin YS, Chou CC, et al. Sitagliptin and cardiovascular outcomes in diabetic patients with chronic kidney disease and acute myocardial infarction: a nationwide cohort study. Int J Cardiol. 2014;181C:200-6.

71. White WB, Cannon CP, Heller SR, Nissen SE, Bergenstal RM, Bakris GL, et al. Alogliptin after acute coronary syndrome in patients with type 2 diabetes. N Engl J Med. 2013;369(14):1327-35.

72. Belfort R, Harrison SA, Brown K, Darland C, Finch J, Hardies J, et al. A placebo-controlled trial of pioglitazone in subjects with nonalcoholic steatohepatitis. N Engl J Med. 2006;355:2297-307.

73. Aithal GP, Thomas JA, Kaye PV, Lawson A, Ryder SD, Spendlove I, et al. Randomized, placebo-controlled trial of pioglitazone in nondiabetic subjects with nonalcoholic steatohepatitis. Gastroenterology. 2008;135:1176-84.

74. Sanyal AJ, Chalasani N, Kowdley KV, McCullough A, Diehl AM, Bass NM, et al. Pioglitazone, vitamin $\mathrm{E}$, or placebo for nonalcoholic steatohepatitis. N Engl J Med. 2010;362:1675-85.

75. Iwasaki T, Yoneda M, Inamori M, Shirakawa J, Higurashi T, Maeda S, et al. Sitagliptine as a novel treatment agent for non-alcoholic fatty liver disease patients with type 2 diabetes mellitus. Hepatogastroenterology. 2011;58(112):2103-5.

76. Itou M, Kawaguchi T, Taniguchi E, Oriishi T, Sata M. Dipeptidil peptidase IV inhibitor improves insulin resistance and steatosis in a refractory non-alcoholic fatty liver disease patient: a case report. Case Rep Gastroenterol. 2012;6:538-44.

77. Ohki T, Isogawa A, Iwamoto M, Ohsugi M, Yoshida H, Toda N, et al. The effectiveness of liraglutide in nonalcoholic fatty liver disease patients with type 2 diabetes mellitus compared to sitagliptin and pioglitazone. ScientificWorld J. 2012;2012:496453.

78. Fruci B, Giuliano S, Mazza A, Malaguarnera R, Belfiore A. Nonalcoholic fatty liver: a possible new target for type 2 diabetes prevention and treatment. Int J Mol Sci. 2013;14:22933-66.

79. Bhatt HB, Smith RJ. Fatty liver disease in diabetes mellitus. HepatoBiliary Surg Nutr. 2015;4(2):101-8.

80. Azoulay L, Yin H, Filion KB, Assayag J, Majdan A, Pollak MN, et al. The use of pioglitazone and the risk of bladder cancer in people with type 2 diabetes: nested case-control study. BMJ. 2012;344, e3645.

81. Wei L, MacDonald TM, Mackenzie IS. Pioglitazone and bladder cancer: a propensity score matched cohort study. Br J Clin Pharmacol. 2013;75:254-9.

82. Schernthaner G, Currie CJ, Schernthaner GH. Do we still need pioglitazone for the treatment of type 2 diabetes? Diabetes Care. 2013;36(2):s155-61.

83. Govindarajan R, Ratnasinghe L, Simmons DL, Siegel ER, Midathada MV, Kim $L$, et al. Thiazolidindiones and the risk of lung, prostate and colon cancer in patient with diabetes. J Clin Oncol. 2007;25(12):1476-81.

84. Mazzone PJ, Rai H, Beukemann M, Xu M, Jain A, Sasighar M. The effect of metformin and thiazolidindione use on lung cancer in diabetics. BMC Cancer. 2012;12:410.

85. Drug Safety Communication FDA. FDA investigating reports of possible increased risk of pancreatitis and pre-cancerous findings of the pancreas from incretin mimetic drugs for type 2 diabetes. 2013.

86. Nelson M, Bhandari N, Wener J. Sitagliptin-induced pancreatitis - a longer road than expected. Clin Case Rep. 2014;2(4):149-52. 
87. Girgis CM, Champion BL. Vildagliptin-induced acute pancreatitis. Endocr Pract. 2011;17(3):48-50.

88. Singh S, Chang HY, Richards TM, Weiner JP, Clark JM, Segal JB. Glucagonlike peptide 1-based therapies and risk of hospitalization for acute pancreatitis in type 2 diabetes mellitus: a population-based matched case-control study. JAMA Intern Med. 2013;25:1-6.

89. Engel SS, Round E, Golm GT, Kaufman KD, Goldstein BJ. Safety and tolerability of sitagliptin in type 2 diabetes: pooled analysis of 25 clinical studies. Diabetes Ther. 2013;4(1):119-45.

90. Łabuzek K, Kozłowski M, Szkudłapski D, Sikorska P, Kozłowska M, Okopień B. Incretin-based therapies in the treatment of type 2 diabetes-More than meets the eye? European I Internal Med. 2013;24(3):207-12.

91. Klarenbach S, Cameron C, Singh S, Ur E. Cost-effectiveness of second-line antihyperglycemic therapy in patients with type 2 diabetes mellitus inadequately controlled on Metformin. CMAJ. 2011;183(16):E1213-20.

92. Minshall M, St. Charles M, Pandya B, Baran RW, Bron M. The cost-effectiveness of pioglitazone compared with sitagliptin: an economic evaluation using a validated economic model from a third party payer perspective in the USA. Value Health. 2007;10(6):A259.

\section{Submit your next manuscript to BioMed Central and take full advantage of:}

- Convenient online submission

- Thorough peer review

- No space constraints or color figure charges

- Immediate publication on acceptance

- Inclusion in PubMed, CAS, Scopus and Google Scholar

- Research which is freely available for redistribution 